\title{
Mi-1-Mediated Aphid Resistance Involves Salicylic Acid and Mitogen-Activated Protein Kinase Signaling Cascades
}

\author{
Qi Li, ${ }^{1}$ Qi-Guang Xie,, Jennifer Smith-Becker, ${ }^{1}$ Duroy A. Navarre, ${ }^{2}$ and Isgouhi Kaloshian' \\ ${ }^{1}$ Department of Nematology, University of California, Riverside, CA 92521, U.S.A.; ${ }^{2}$ Vegetable and Forage Crop Research \\ Unit, USDA- Agricultural Research Service, Washington State University, Prosser, WA 99350, U.S.A.
}

Submitted 2 November 2005. Accepted 5 February 2006.

\begin{abstract}
The tomato $\mathrm{Mi}-1$ gene confers resistance to root-knot nematodes (Meloidogyne spp.), potato aphids (Macrosiphum euphorbiae), and whiteflies (Bemisia tabaci and B. tabaci biotype $B$ ). Resistance to potato aphid is developmentally regulated and is not associated with induction of a hypersensitive response. The $N a h G$ transgene that eliminates endogenous salicylic acid (SA) was used to test the role of the SA signaling pathway in the resistance mediated by $\mathrm{Mi}-1$ to potato aphids. Aphids survived longer on NahG tomato plants than on wild type. However, aphid reproduction was not affected on $N a h G$ tomato. Aphid resistance in Mi-1 NahG plants was completely abolished and the phenotype was successfully rescued by application of BTH (benzo(1,2,3)-thiaiazole-7-carbothioic acid $S$-methyl ester), indicating that the SA signaling pathway is an important component of $\mathrm{Mi}$-1-mediated aphid resistance. Using virusinduced gene silencing, one or more mitogen-activated protein kinase (MAPK) cascades required for $\mathrm{Mi}$-1-mediated aphid resistance were identified. Silencing plants for MAPK kinase (LeMKK2) and MAPKs (LeMPK2 and LeMPK1, or $L e M P K 3)$ resulted in attenuation of $M i-1-$ mediated aphid resistance. These results further demonstrate that resistance gene-mediated signaling events against piercing-sucking insects are similar to those against other plant pathogens.
\end{abstract}

Additional keywords: gene-for-gene resistance, resistance signaling.

Plants are continuously attacked by an array of biotic and abiotic agents and, consequently, require efficient defensive mechanisms for their survival. Besides physical barriers at the surface of plant tissues, basal plant defense is the first line of active defense against invading pathogens and pests (Hammond-Kosack and Parker 2003). Although basal defense does not drastically limit the growth and multiplication of pests and pathogens, it limits disease severity. Another form of plant defense is mediated by plant resistance $(R)$ genes and is known as gene-for-gene resistance (Flor 1971). $R$ gene-mediated plant defense involves direct or indirect recognition of the pathogen or pest avirulence ( $a v r$ ) gene product by the $R$ gene product. One of the hallmarks of defense responses triggered by this recognition is cell death known as the hypersensitive response (HR).

Corresponding author: I. Kaloshian; Telephone: +1.951.827.3913; Fax: +1.951.827.3719; E-mail: isgouhi.kaloshian@ucr.edu

Current address of Qi-Guang Xie: Department of Biology, University of Tennessee, Nashville, TN, U.S.A.
Plant disease resistance responses involve global changes in gene expression mediated by multiple signaling pathways (Hammond-Kosack and Parker 2003; Nimchuk et al. 2003). These defense pathways are mediated by a number of small molecules, including salicylic acid (SA), jasmonic acid (JA), and ethylene (ET) (Kunkel and Brooks 2002). Gene expression profiling experiments indicate that there is significant overlap between these pathways (Schenk et al. 2000). These molecules play major roles in signaling by either activating, repressing, or both the signal transduction of downstream components that activate plant defenses.

Resistance to potato aphid (Macrosiphum euphorbiae) in tomato is conferred by $M i-1$, which encodes a protein with a coiled-coil nucleotide-binding site and leucine-rich repeat motifs (Milligan et al. 1998; Rossi et al. 1998). In addition to aphid resistance, $\mathrm{Mi}-\mathrm{I}$ also confers resistance in tomato to three species of root-knot nematodes (Meloidogyne arenaria, $M$. incognita, and M. javanica) and to whiteflies (Bemisia tabaci and $B$. tabaci biotype B) (Milligan et al. 1998; Nombela et al. 2003). Although $M i-1$ is constitutively expressed in both roots and leaves, $M i-1-$ mediated resistance is differentially regulated (Martinez de Ilarduya and Kaloshian 2001). Resistance to nematodes is expressed soon after germination, while resistance to both aphids and whiteflies is first expressed in five-weekold plants (Kaloshian et al. 1995; Pascual et al. 2000). In adult plants, fully expanded leaves are resistant to aphids, irrespective of leaf position on the plant, while expanding leaves remain aphid-susceptible throughout the life of the plant (Kaloshian et al. 1997). Since $M i-1$ transcripts are present in leaves and roots early in development, it is possible that $\mathrm{Mi}-\mathrm{l}$ is posttranscriptionally regulated differently in roots and leaves (Martinez de Ilarduya and Kaloshian 2001). Alternatively, another key component in the resistance signaling pathway is developmentally regulated differentially in roots and leaves.

Another distinction between nematode and aphid resistance is in the differing ability of these two pests to induce HR in resistant tissues. Resistance to root-knot nematodes is associated with HR in roots after infective-stage juveniles initiate feeding, while no HR is detected in the resistant leaves after aphid feeding (Martinez de Ilarduya et al. 2003). Resistance to aphids in $M i-1$ plants is manifested by reduced feeding, fecundity, and survival (Kaloshian et al. 1997; Kaloshian et al. 2000). Death likely occurs due to starvation and desiccation, since aphids appear to recover fully when transferred from resistant to susceptible tomato genotypes (Kaloshian et al. 1997).

Limited information exists about $R$ gene-mediated resistance to piercing-sucking insects (Kaloshian 2004). In the genetically tractable plant species Arabidopsis, mutational approaches have been used to identify components of plant defense signaling. The majority of screens to date have identified genes that 
play roles in multiple $R$ gene-mediated resistances indicating that common signaling networks operate downstream of a number of gene-for-gene type resistances. These important genetic resources could not be used to dissect $M i-1$-mediated resistance since $M i-1$ does not function in Arabidopsis (V. M. Williamson, personal communication). Suppressor screens of $\mathrm{Mi}-1$ tomato identified an additional gene, Rmel, that is required for resistance to aphids, whiteflies, and nematodes (Martinez de Ilarduya et al. 2001, 2004). Rmel functions early in the $M i-1$ signaling cascade and appears to be specific for $\mathrm{Mi}-\mathrm{l}$ function (Martinez de Ilarduya et al. 2001, 2004).

Since the resistance pathways of many $R$ genes converge, obvious candidates of the $M i-1$-mediated resistance signaling are genes involved in other $R$ gene-mediated resistance signaling. Mitogen-activated protein kinases (MAPKs) underlie plant defense signaling and are activated by a range of stimuli including $R$ gene-mediated defense responses (Jin et al. 2003; Liu et al. 2004; Pedley and Martin 2004; Romeis et al. 1999, 2001; Tena et al. 2001; Zhang and Klessig 2000, 2001). MAPK activity is regulated by a three-step phosphorylation cascade involving activation of the MAPK by its upstream MAPKK, which in turn is activated by an upstream MAPKKK. The tobacco MAPKs, SA-induced protein kinase (SIPK), and wound-induced protein kinase (WIPK) are activated by the MAPKK MEK2 in the $N$ gene-mediated resistance to Tobacco mosaic virus (TMV) (Jin et al. 2003; Zhang and Klessig 1998). Similarly, activation of SIPK and WIPK has been reported in $C f 9$-mediated resistance to the fungal pathogen Cladosporium fulvum (Romeis et al. 1999). The tomato homolog of NtWIPK (LeMPK3) and another MAPK, LeMPK2, are activated by LeMKK2 (MEK2) and in response to Pto-mediated resistance to the bacterial pathogen Pseudomonas syringae pv. tomato (Pedley and Martin 2004). LeMPK3 is also activated by defense responses against bacterial pathogen Xanthomonas campestris pv. vesicatoria (Mayrose et al. 2004).

Using virus-induced gene silencing (VIGS), the function of MAPKs and their upstream kinases were identified as important components of $R$ gene-mediated resistance. This reverse genetic tool allows rapid and transient suppression of host genes by targeting sequence-specific degradation of their transcripts (Burch-Smith et al. 2004; Ding et al. 2004). Silencing a MAPKKK (NPK1), two MAPKKs (NtMEK1 and NtMEK2), and three MAPKs (SIPK, WIPK, and Ntf6) resulted in attenuation of $N$-mediated resistance to TMV (Jin et al. 2002; Liu et

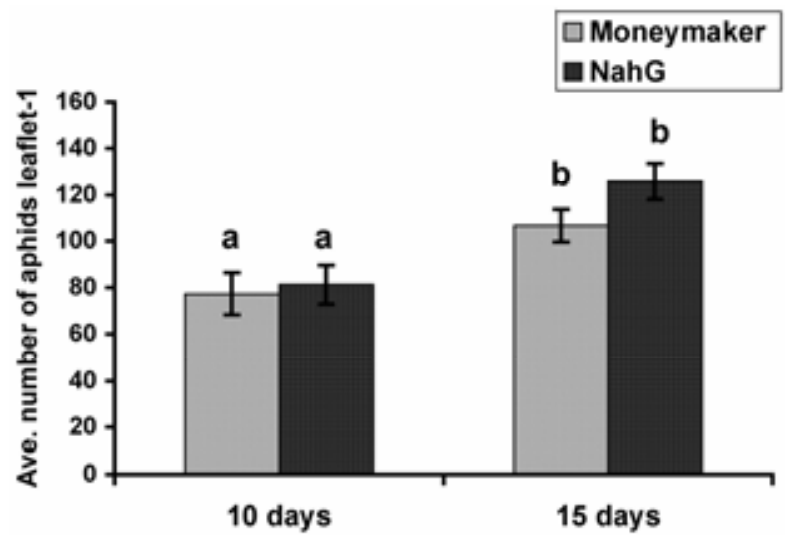

Fig. 1. Aphid choice assays on tomato plants expressing $N a h G$ and the wild type cv. Moneymaker. Five-week-old plants were exposed to potato aphids in insect cages in a greenhouse and were evaluated at 10 and 15 days after aphid exposure. Six plants of each genotype were used. The experiment was performed twice with similar results. Data representing means from one experiment are presented. Error bars indicate \pm standard error. Bars with different letters denote a significant difference at $P<0.05$. al. 2004). Silencing $N P K 1$ also compromised $B s 2$ - and $R x$-mediated avirulence-specific HR (Jin et al. 2002). Similarly, silencing WIPK and SIPK compromised resistance to Pseudomonas cichorii (Sharma et al. 2003). In tomato, silencing homologs of NtMEK1 (LeMKK1), NtMEK2 (LeMKK2), WIPK (LeMPK3), and Ntf6 compromised Pto-mediated resistance (Ekengren et al. 2003).

Despite a wealth of information on genes participating in $R$ gene-signaling pathways, to date there has been no examination of the functional role of these genes in $R$ gene-mediated resistance to herbivores. Similarly, no information exists about the functional role of SA in $R$ gene-mediated resistance to piercing-sucking insects. In the work presented in this paper, forward genetic approaches were used to examine the role of the SA signaling pathway in $M i-1-$ mediated aphid resistance. Transgenic tomato plants expressing $\mathrm{NahG}$, a gene from $\mathrm{Pseu}$ domonas putida that encodes an enzyme that metabolizes SA (Gaffney et al. 1993) were used, and a major role for SA in $\mathrm{Mi}$ 1-mediated resistance to potato aphids was identified. In addition, VIGS was used to identify one or more MAPK pathways required for the full $M i-1$ function against aphids.

\section{RESULTS}

The role of SA in basal resistance to potato aphid.

To assess a role for SA in aphid defense, the interaction of the potato aphid on wild-type Moneymaker and NahG tomato plants was compared. Plants were maintained in growth chambers at low light intensity until used for aphid screens, since high light intensity caused necrotic lesions on leaves of $N a h G$ tomato plants. Two distinct assays were performed. Choice assays allowed the determination of plant-specific feeding preferences of the aphids. The number of aphids was evaluated in choice assays at 10 and 15 days after exposure to aphids (Fig. 1). Significant differences in aphid numbers were observed between day 10 and day 15 on both genotypes $(P<0.05)$. However, no significant differences were observed between the numbers of aphids on Moneymaker and on NahG during either time period $(P>0.05)$. In a second assay, the survival and fecundity of aphids were monitored on a daily basis on Moneymaker and NahG plants, using a no-choice assay and one-dayold adult aphids. The percent daily adult survival was $10 \%$ higher on $N a h G$ than on Moneymaker plants, with significant effect manifested after day 12 (Fig. 2A). At this time, aphids produced similar numbers of progeny per day on $N a h G(2.94 \pm$ $0.15)$ and the wild-type Moneymaker $(2.82 \pm 0.23)$ plants $(P>$ $0.05)$. However, the total number of progeny per aphid was significantly higher on $N a h G$ tomato than on Moneymaker $(P<$ 0.05 ), since aphids lived longer on $N a h G$ plants (Fig. 2B).

\section{Genetic crosses and evaluation of SA levels.}

To determine if SA has a role in aphid resistance mediated by $M i-1$, we crossed tomato cv. VFN (Mi-1/Mi-1) with cv. Moneymaker (mi-1/mi-1) containing the NahG transgene (Brading et al. 2000). To confirm that the F1 progeny were hybrids, DNA was isolated and analyzed using polymerase chain reaction (PCR) for the codominant marker REX-1, which lies within 250 $\mathrm{kb}$ of $\mathrm{Mi}-\mathrm{I}$ in the Solanum peruvianum introgressed region of resistant tomato (Kaloshian et al. 1998; Williamson et al. 1994). All F1 progeny tested were heterozygous for the REX-1 allele, indicating that they were true hybrids (data not shown).

To confirm the integrity of $N a h G$ and its ability to convert SA into catechol, SA levels were measured in the hybrid and parental types. For evaluation of SA levels in leaves, we inoculated four-week-old seedlings with Pseudomonas syringae pv. syringae to induce HR and SA accumulation. Significantly higher levels of total SA (free SA and bound SA glucoside [SAG]) were 
detected in cv. VFN infiltrated with $P$. syringae pv. syringae than in leaflets of all genotype-treatment combinations tested $(P<$ 0.0001) (Fig. 3). Endogenous SA levels were also significantly higher in cv. VFN leaves than in $N a h G$ or VFN $\times N a h G$ leaves $(P<0.0001)$, indicating that $N a h G$ expression prevented the accumulation of SA in VFN $\times N a h G$ leaves (Fig. 3).

\section{$M i$-1-dependent $P R$ - 1 transcript accumulation in NahG plants.}

Previous work has indicated that transcripts of $P R-1$ (also known as $P 4$ ), a SA-inducible gene, accumulated after potato aphid feeding in $\mathrm{Mi}-1$ plants (Martinez de Ilarduya et al. 2003; van Kan et al. 1995). The ability of VFN $\times N a h G$ plants to accumulate $P R-1$ transcripts after aphid feeding was evaluated. $M i-1-$ mediated aphid resistance is developmentally regulated, with plants becoming resistant five weeks after germination. Since plants used in these experiments were maintained at low light intensity, plants reached the appropriate stage of development around nine weeks of age. Therefore, timecourse infestations of tomato leaflets with potato aphids were performed with nine-week-old plants. In the resistant interaction of VFN (Mi-1/Mi-1) plants infested with potato aphid, appreciable levels of $P R-1$ transcript started accumulating in infested leaflets within $12 \mathrm{~h}$ after infestation (Fig. 4). Transcript levels remained high at both 24 and $48 \mathrm{~h}$ after aphid infestation. The $N a h G$ transgene had a profound effect on $P R-1$ transcript accumulation in tomato plants after aphid infestation (Fig. 4). Within the first $24 \mathrm{~h}$ after aphid infestation, no $P R-1$ transcripts could be detected in potato aphid-infested leaflets of NahG plants or of

\section{A}

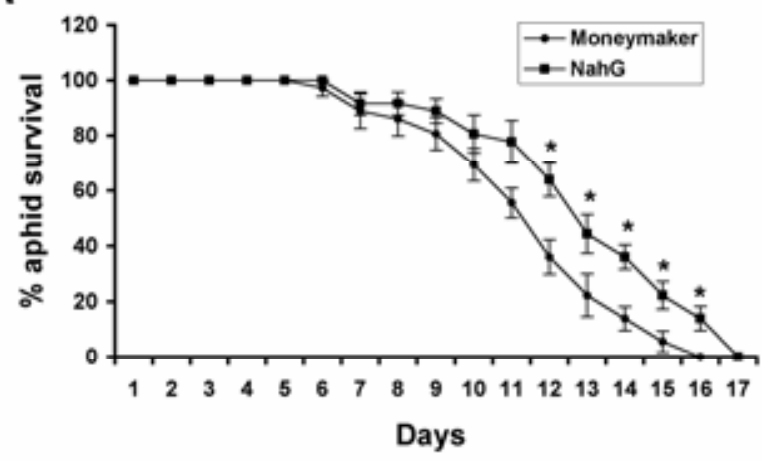

B

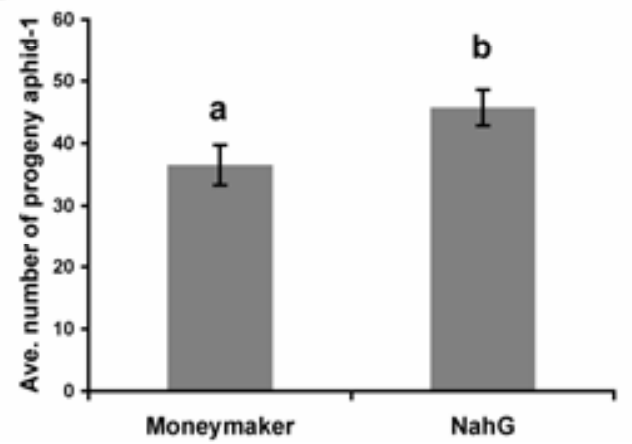

Fig. 2. Aphid survival and fecundity on tomato plants expressing $N a h G$ and the wild-type cv. Moneymaker. Five-week-old tomato seedlings were used in no-choice assays. Plants were individually infested with four oneday-old adult aphids. Aphid survival was monitored on a daily basis until all aphids were dead. Nine plants of each genotype were used. Experiment was performed once. Error bars indicate \pm standard error. A, Daily aphid survival. Statistical analysis was performed on arcsin-transformed data and significant differences at $P<0.05$ are indicated by an asterisk (*). B, Aphid reproduction. Bars with different letters denote a significant difference at $P<0.05$
$\mathrm{VFN} \times N a h G$, indicating that accumulation of $P R-1$ transcripts by aphid feeding is at least partially mediated by SA (Fig. 4). $P R-1$ transcripts were first detected at $48 \mathrm{~h}$ after aphid infestation in both $N a h G$ and $\mathrm{VFN} \times N a h G$ plants (Fig. 4).

\section{Expression}

of $N a h G$ compromises $M i-1-$ mediated aphid resistance.

Aphid infestations were evaluated in a preliminary choice assay on cv. VFN, NahG, and the VFN $\times N a h G$ hybrid. Differences in the number of aphids feeding on leaves of plants from these genotypes were observed. Higher numbers of aphids were observed on the VFN $\times N a h G$ than on cv. VFN, suggesting a role for $\mathrm{SA}$ in $\mathrm{Mi}$-1-mediated resistance to potato aphids (data not shown). To confirm that the absence of SA is responsible for increased aphid colonization and not the accumulation of catechol or an indirect effect on another pathway, we repeated the choice experiment and included an additional treatment. In the second choice experiment, half of the plants were sprayed with benzo(1,2,3)-thiaiazole-7-carbothioic acid $S$-methyl ester (BTH) and the other half with water. BTH is a SA analog that activates the SA signaling pathway downstream of SA (Friedrich et al. 1996). As in the previous experiment, significantly higher numbers of aphids were present on the VFN $\times N a h G$ plants than on cv. VFN and these aphid numbers were not significantly different than the numbers on $N a h G$ plants $(P<0.05)$ (Fig. 5). The number of aphids on VFN $\times$ $N a h G$ treated with BTH was similar to those on cv. VFN, indicating that BTH was able to restore the resistant phenotype in VFN $\times N a h G$ plants (Fig 5). The observation that BTH application was not able to induce resistance in $N a h G \mathrm{cv}$. Moneymaker plants supports a role for SA in the $M i-1$-mediated pathway rather than induction of a resistance mechanism unrelated to $M i-1$ (Fig. 5).

\section{Silencing of $M i-1$ in leaves using TRV in VIGS.}

To determine whether VIGS could be used to silence $M i-1-$ mediated resistance to aphids, Tobacco rattle virus (TRV) was used in VIGS to silence $M i-1$. A cDNA fragment, spanning the carboxy terminal end of the $M i-1$ gene, was cloned into

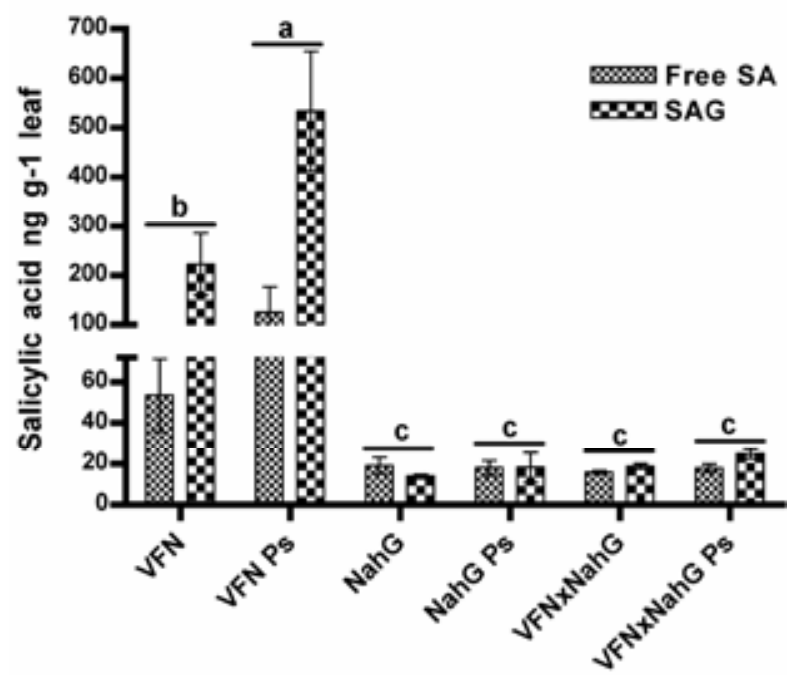

Fig. 3. Quantification of salicylic acid (SA) in tomato leaves. Tomato leaves of cv. VFN, NahG, and VFN $\times N a h G$ were inoculated with either Pseudomonas syringae pv. syringae (Ps) or water. Both free SA and bound SA (salicylic acid glucoside [SAG]) were measured. Two plants per genotype treatment were used. SA was measured in two subsamples from each genotype treatment. Error bars indicate \pm standard error. Statistical analysis was performed on total SA levels (free SA plus SAG). Bars with different letters denote a significant difference at $P<0.0001$. 
pTRV2, resulting in clone pTRV2:Mi-1 (Liu et al. 2002). Near-isogenic tomato cv. Motelle $(\mathrm{Mi}-1 / \mathrm{Mi}-1)$ and Moneymaker (mi-l/ $m i-1)$ were agroinfiltrated with pTRV1 plus pTRV2:Mi-1, pTRV1 plus pTRV2 empty vector, or infiltration buffer. We refer to the first plasmid combination as TRV:Mi-1, the second as TRV. Plants used in VIGS and controls were screened with aphids using a no-choice assay, and aphid survival was monitored on a daily basis. VIGS in tomato is known to be uneven in its expression (Ekengren et al. 2003; Liu et al. 2002). Consequently, leaflets used in the no-choice aphid assays were chosen randomly, because the extent of silencing in individual leaflets could not be predicted in advance. Seven to 10 days after aphid infestations, similar numbers of aphids were present on the susceptible Moneymaker plants treated with buffer or agroinfiltated with TRV or Mi-l VIGS construct (Figs. 6A and 7A), indicating that neither Agrobacterium culture nor TRV interfered with aphid feeding. Over the same time period, almost all aphids on the genetically resistant Motelle plants infiltrated with TRV were dead (Figs. 6A and 7B). Aphids on Motelle plants treated with buffer also died over a similar time period (Fig. 6A), indicating that neither Agrobacterium culture nor TRV hindered the $M i-1-$ mediated resistance to aphids. In contrast, aphids were still alive and reproducing on most Motelle plants agroinfiltrated with $\mathrm{Mi}-1$ VIGS construct (Fig. 7C). The number of aphids on Motelle leaflets agroinfiltrated with TRV:Mi-1 varied greatly (Fig. 6A). The aphid numbers ranged from zero aphids, indicating no silencing, to over 60 aphids, indicating a high level of silencing.

Leaflets of Motelle tomato agroinfiltrated with Mi-1 VIGS construct and harboring aphids were collected for RNA extraction and were used in semiquantitative analysis for the evaluation of the relative abundance of $M i-1$ transcript levels. RNAs from a total of 10 leaflets were subjected to reverse transcriptase (RT)-PCR analysis using $M i-1$ gene-specific primers (Table 1). All indicated reduction in $M i-1$ transcript levels compared with TRV-only agroinfiltrated plants (Fig. 6B). The VIGS results indicated that TRV-VIGS is able to silence the $M i-1$ gene and attenuate $M i-1-$ mediated resistance to aphids. This approach could therefore be used to examine potential downstream regulators of the $M i-1$ pathway.

\section{Silencing of members of MAPK cascades.}

MAPK cascades have a major role in signaling $R$ gene-mediated resistance to various pathogens (Ekengren et al. 2003; Jin et al. 2002, 2003; Liu et al. 2004; Romeis et al. 1999; Zhang and Klessig 2001). Several of these MAPKs were chosen to evaluate their roles in $M i-1$-mediated resistance to potato aphids. Using VIGS, we targeted the MAPK LeMKK2 and the three MAPKs LeMPK1, LeMPK2, and LeMPK3. LeMKK2 is known to phosphorylate all three MAPKs (Pedley and Martin 2004). We made use of existing VIGS constructs that silence these genes in tomato, NtMEK2 and NbWIPK, which silence LeMKK2 and LeMPK3, respectively (Ekengren et al. 2003).
However, no constructs were available that allowed gene-specific silencing of LeMPK1 and LeMPK2. These genes have $89.2 \%$ nucleotide identity and have no distinct stretches of DNA in the coding regions that can be targeted for gene-specific silencing (Holley et al. 2003). Therefore, a NbNtf4 VIGS construct was used to simultaneously silence both genes. Limited regions at the $3^{\prime}$ and $5^{\prime}$ ends of LeMPK1 and LeMPK2 allowed us to design gene-specific primers (Table 1).

Aphid no-choice assays with tomato plants infiltrated with the NtMEK2 VIGS construct resulted in attenuation of $M i-1-$ mediated aphid resistance (Fig. 7D). Aphids survived on leaflets from the genetically resistant Motelle plants agroinfiltrated with the VIGS construct NtMEK2 (Fig. 8A). RT-PCR results demonstrated that LeMKK2 RNA is less abundant in NtMEK2-agroinfiltrated plants harboring aphids (Fig. 8B), indicating a role for LeMKK2 in the Mi-1-mediated aphid resistance. Similarly, aphids were able to survive on Motelle plants agroinfiltrated with NbNtf4 (Fig. 7E) and NbWIPK (Fig. 7F) VIGS constructs. As expected, leaflets supporting aphid growth agroinfiltrated with the NbNtf4 construct resulted in reduction of both LeMPK1 and LeMPK2 transcript levels (Fig. 8B). The identity of these transcripts was confirmed by sequencing (data not shown). A marked reduction in relative abundance of LeMPK3 transcript levels was detected in leaflets with aphids agroinfiltrated with the NbWIPK construct compared with the TRV control (Fig. 8B).

The number of aphids on Motelle tomato leaflets agroinfiltrated with $N t M E K 2, N b W I P K$, or NbNtf4 was variable (Fig. 8A), similar to Motelle leaflets agroinfiltrated with TRV:Mi-1, in which a range of aphid numbers ( 0 to 63 ) was observed. The number of aphids on randomly caged leaflets agroinfiltrated with these constructs ranged between 0 to 40 (Fig. 8A).

\section{DISCUSSION}

$\mathrm{SA}$ is required for full function of a number of $R$ genes. Several mutants in the SA signaling pathway have been used to identify the role of this signal molecule in $R$ gene-mediated resistance to several pathogens in Arabidopsis (Glazebrook 2001; Hammond-Kosack and Parker 2003). In tobacco and tomato, information about a role for $\mathrm{SA}$ in $R$ gene-mediated resistance has been obtained, mostly using transgenic plants expressing $N a h G$. Using a $N a h G$ line, our results indicate a major role for $\mathrm{SA}$ in $M i-1-$ mediated resistance to potato aphids. A role for SA in $\mathrm{Mi}-1-$ mediated resistance to root-knot nematodes has also been shown (Branch et al. 2004). Tomato plants with $M i-1$ and expressing $N a h G$ failed to accumulate constitutive levels of SA and were hindered in their ability to accumulate SA after elicitation of HR by $P$. syringae pv. syringae. Expression of $N a h G$ also attenuated $P R-1$ transcript accumulation after aphid infestation in $M i-1$ tomato. Although the role of $P R-1$ in plant defense is not well-defined, $P R-1$ is one of the hallmark genes associated with the SA signaling path-

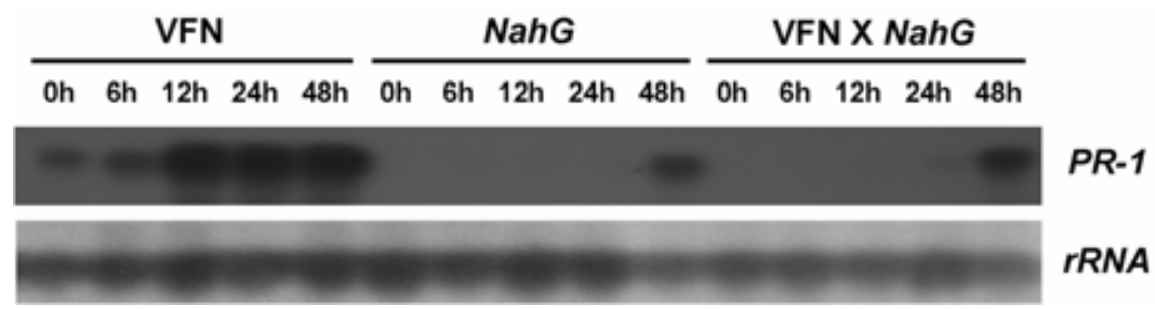

Fig. 4. Pathogenesis-related protein $(P R-1)$ transcript accumulation in cv. VFN, NahG, and VFN $\times N a h G$ plants after potato aphid infestations. An avirulent biotype of the potato aphid was used to infest nine-week-old tomato plants, using leaf cages. Samples of the infested leaflet were collected at 0 , $6,12,24$, and $48 \mathrm{~h}$ after aphid infestation. Total RNA was isolated, and the RNA blot (15 $\mu \mathrm{g}$ per lane) was hybridized with ${ }^{32} \mathrm{P}-\mathrm{labeled} P R-1$ probe. A $18 \mathrm{~S}$ rRNA probe was used as a control to assess RNA loading and transfer. 
way and is upregulated in $\mathrm{Mi}-1-$ mediated resistance to aphids (Martinez de Ilarduya et al. 2003).

Catechol does not appear to play a role in the susceptibility of NahG Mi-l plants, since the SA analog BTH restored aphid resistance to $N a h G M i-1$ plants. Similar results were reported for $\mathrm{Mi}-1-$ mediated resistance to root-knot nematodes, in which incorporation of BTH into root-growth media restored $\mathrm{Mi}-1$ resistance to root-knot nematodes in transgenic hairy roots expressing NahG (Branch et al. 2004). NahG plants often exhibit pleiotropic effects in Arabidopsis. ET production was reduced by more than $50 \%$ in Arabidopsis expressing NahG after inoculation with either virulent or avirulent strains of $P$. syringae pv. tomato or Xanthomonas campestris pv. vesicatoria (Heck et al. 2003; O'Donnell et al. 2003). Therefore, it is possible that $\mathrm{Mi}$ 1 NahG plants are also affected in the ET signaling pathway.

Aphids were able to live longer on $N a h G$ plants compared with the wild-type parent, indicating increased susceptibility of $N a h G$ plants to potato aphids. This increased survival on $N a h G$ tomato could be due to affects on signaling pathways that are not SA-dependant. Alternatively, it could indicate a role for SA in basal defense against aphids. SA has been implicated previously in plant defense against piercing-sucking insects (Kaloshian and Walling 2005). Both accumulation of SA after aphid feeding and induction of systemic acquired resistance by SA or its analogs against aphids have been demonstrated in other plant species (Chaman et al. 2003; Havlickova et al. 1998). In tomato, application of BTH resulted in a decrease in colonization of susceptible (mi-1/mi-1) and resistant $(M i-1 / M i-1)$ tomato by potato aphids (Cooper et al. 2004). BTH treatments in our experiments did not result in a decrease in colonization of $\mathrm{Mi}-1$ tomato by potato aphids. This could be due to the high degree of $M i-1$ resistance against the biotype of potato aphid used in our assays. Different levels of resistance of $\mathrm{Mi}-\mathrm{l}$ tomato have been reported against distinct biotypes of the aphid (Goggin et al. 2001).

We demonstrated the use of VIGS to silence $M i-1$ in tomato. The scarcity of $R$ gene signaling mutants in tomato makes this forward genetics approach highly desirable. In tomato, variation in silencing is often seen within a plant and within a single leaflet. For example, it has been shown that VIGS in tomato plants is not uniform using phytoene desaturase $(P D S)$ as a target, which results in a clear visual phenotype in leaves. (Ekengren et al. 2003; Liu et al. 2002). Thus, it is not surprising that lower numbers of aphids were alive on $M i$ - 1 -silenced leaflets than on susceptible Moneymaker tomato leaflets. In caged leaf-

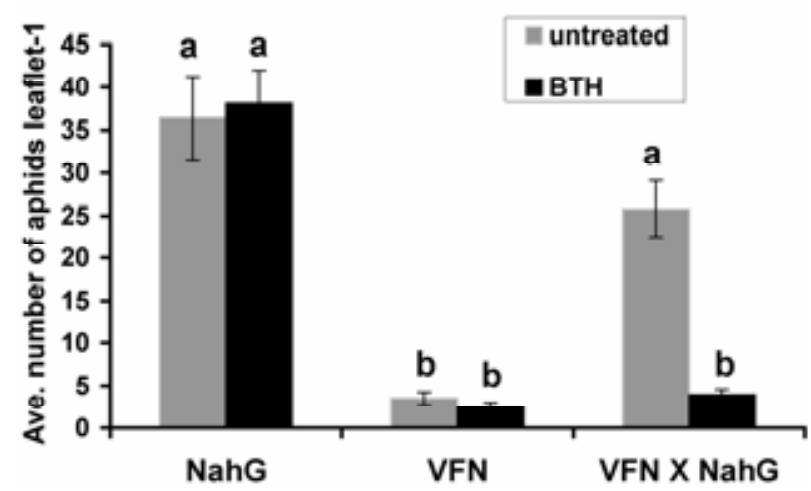

Fig. 5. Effect of $N a h G$ expression and BTH (benzo(1,2,3)-thiaiazole-7-carbothioic acid $S$-methyl ester) treatment on potato aphid colonization. Aphid choice assays of nine-week-old tomato plants were performed in insect cages in a greenhouse. Eight plants were used for each genotype treatment. The experiment was performed twice with similar results. Data representing means from one experiment are presented. Error bars indicate \pm standard error. Bars with different letters denote a significant difference at $P<0.05$. lets, aphids are free to move and have access to the entire leaflet. Therefore, it is likely that they will probe leaf tissues where $M i-1$ is not silenced, which will decrease the overall feeding success. Silencing $M i-1$ resulted in greater aphid survival and reproduction compared with silencing the other genes used in this study. Silencing members of one or more MAPK cascades attenuated partially the $\mathrm{Mi}-1$-mediated aphid resistance, indicating that other unaffected pathways also contribute to $\mathrm{Mi}-1$ resistance to aphids.

Our results indicate a role for one or more MAPK cascades downstream of $M i-1$. The activity of the tomato MAPKs LeMPK1, LeMPK2, and LeMPK3 is induced by a number of biotic and abiotic elicitors (Holley et al. 2003; Mayrose et al.

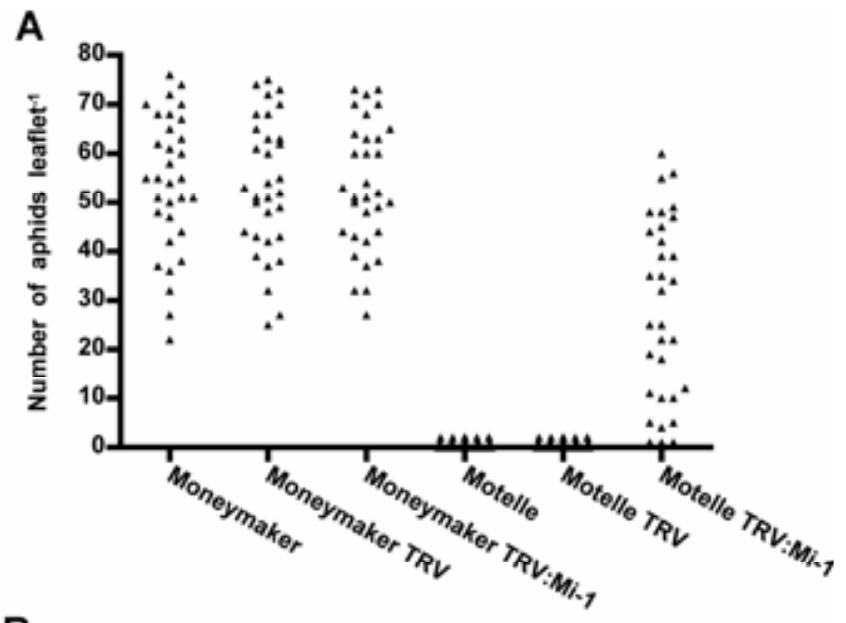

B

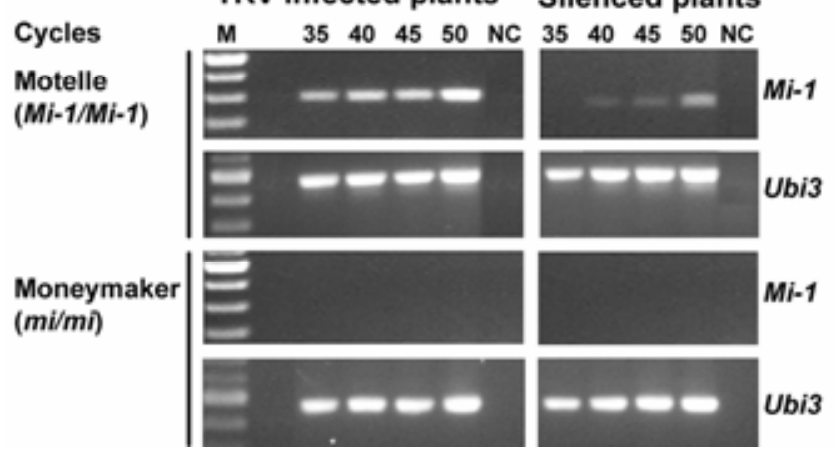

Fig. 6. Aphid survival and $M i-1$ expression in tomato leaflets silenced for $M i-1$ and in control leaflets. Near-isogenic tomato cvs. Motelle (Mi-1/Mi-1) and Moneymaker (mi-1/mi-1) were used. Cultures of Agrobacterium tumefaciens GV3101 containing pTRV1, pTRV2:Mi-1, or pTRV2 empty vector were used. The pTRV1 plus pTRV2:Mi-1 combination is referred to as TRV:Mi-1 and pTRV1 plus pTRV2 empty vector is referred to as TRV. Controls were infiltrated with buffer. Six weeks after infiltration, plants were assayed with aphids. A, Aphid survival on control leaflets and leaflets agroinfiltrated with TRV:Mi-1. Triangles represent the number of aphids (adult and nymphs) on a single infested leaflet. Four leaflets per plant were infested with potato aphids, and eight plants per genotype treatment were used in each experiment. At 7 to 10 days after infestations, plants were evaluated by counting the number of aphids on each caged leaflet. Four independent experiments were performed. Data from one experiment is presented. B, Effect of TRV:Mi-1 on Mi-1 transcript levels in tomato leaflets from cv. Motelle (Mi-1/Mi-1). Ethidium bromide-stained $1.5 \%$ agarose gels with reverse transcriptase-polymerase chain reaction (PCR) products. cDNA was synthesized from total RNA isolated from individual leaflets from plants agroinfiltrated with TRV or TRV:Mi-1 supporting aphid growth in the aphid bioassays. For Mi-1-specific amplification, primers VIGS-F and C2S4 were used. Amplification of the tomato ubiquitin $\mathrm{Ubi3}$ gene was used as an internal control for equal cDNA use from control and silenced plants. PCR cycles are as indicated on the top of the panels. Lane ' $\mathrm{M}$ ' indicates DNA ladder and ' $\mathrm{NC}$ ' indicates the negative control in which RNA was used as template in the absence of reverse transcriptase. 
2004). In Arabidopsis, using macroarray analysis, upregulation of AtMAPK3, the Arabidopsis ortholog of LeMPK3, was reported $72 \mathrm{~h}$ after aphid feeding; however, this induction was not consistent (Ichimura et al. 2002; Moran et al. 2002). Our results establish a positive role for LeMPK3 in aphid defense signaling pathway mediated by $M i-1$.

Direct roles of the tomato and tobacco MAPKKs and MAPKs have been demonstrated using VIGS in Pto- and $\mathrm{N}$ mediated resistance to $P$. syringae pv. tomato and TMV, respectively (Ekengren et al. 2003; Jin et al. 2003; Liu et al. 2004). Here, we demonstrate the requirement of LeMKK2 and three MAPKs, LeMPK1, LeMPK2, and LeMPK3 for Mi-1-mediated aphid resistance. These results suggest that one or more similar MAPK cascades operates downstream of distinct $R$ genes and that common defense pathways might be activated in resistance to diverse pests and pathogens. Recently, a MAPKKK, NbMAPKKK $\alpha$, was isolated and VIGS was used to demonstrate that NbMAPKKK $\alpha$ acts upstream of $N b M E K 2$ and SIPK but not WIPK in the Pto-mediated incompatible HR cell death pathway (del Pozo et al. 2004). Although NbMEK2 phosphorylates both SIPK and WIPK, this data indicates that these two MAPKs are activated by distinct MAPKKKs; therefore, the MAPK module used in this study could represent more than one signaling cascade (del Pozo et al. 2004; Jin et al. 2003).

LeMPK1 and LeMPK2 are closely related with over $89 \%$ nucleotide sequence identity (Holley et al. 2003). Most likely, the VIGS construct used to silence LeMPK1 in tomato also silenced LeMPK2 (Ekengren et al. 2003). Similarly, the VIGS construct used to silence SIPK in Nicotiana spp. presumably also silenced Ntf4 (Liu et al. 2004). Our data indicate that the VIGS construct used in this study silenced both LeMPKI and LeMPK2 (Fig. 8B). Therefore, these experiments can not rule out a role for $L e M P K 2$ or its orthologs in plant resistance. It is possible that both $L e M P K 1$ and $L e M P K 2$ are required for plant defense, suggesting that all three MAPKs are required for $\mathrm{Mi}$ $1-$ mediated resistance against aphids. Alternatively, LeMPK1 and LeMPK2 may have redundant functions, so that silencing of both genes is required to affect their functional role. Indeed,
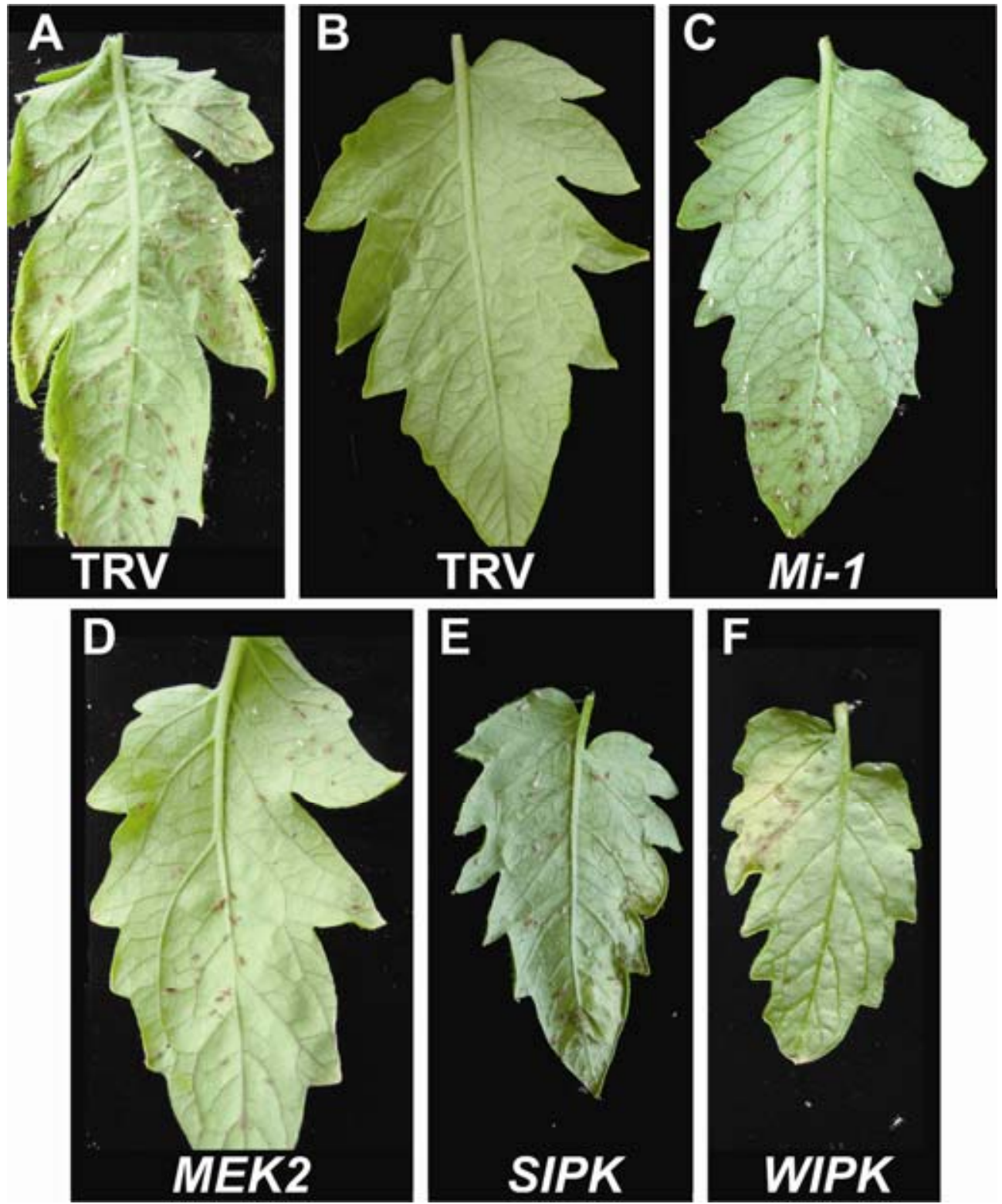

Fig. 7. Phenotype of leaflets used in virus-induced gene silencing experiments. A, Moneymaker (mi-1/mi-1) leaflet agroinfiltrated with pTRV1 plus pTRV2 empty vector (TRV). B, Motelle (Mi-1/Mi-1) leaflet agroinfiltrated with TRV. C through F, Leaflets of Motelle agroinfiltrated with TRV containing the following constructs: $\mathbf{C}, M i-1, \mathbf{D}, N t M E K 2$, E, NbNtf4, and $\mathbf{F}, N b W I P K$. Individual leaflets were infested with 25 adults and nymphs of potato aphids in leaf cages. Photographs were taken 7 to 10 days after aphid infestations, and representative leaflets are shown. 
recent information points to functional redundancy of $S I P K$ and Ntf4 (S. Zhang, personal communication).

Our work identified SA as a key signal molecule in $\mathrm{Mi}-1-$ mediated aphid resistance. In addition, we identified members of one or more MAPK cascades that are also members of $\mathrm{Mi}-1$ signal transduction. Previously, only one gene, Rme1, has been identified as required for $\mathrm{Mi}-\mathrm{I}$-mediated resistance to aphids, nematodes, and whiteflies (Martinez de Ilarduya et al. 2001, 2004). The rmel mutant was isolated in a suppressor screen for $M i-1-$ mediated nematode resistance, but the nature of Rme1 awaits cloning of the gene. VIGS will accelerate the identification of other members of the $\mathrm{Mi}-\mathrm{I}$ signaling cascade.

\section{MATERIALS AND METHODS}

Plant materials and growth conditions.

The tomato cultivars and mutants used in this study were VFN $(M i-1 / M i-1)$, UC82B (mi-1/mi-1), the near-isogenic Mo-

Table 1. Genes targeted in VIGS and gene-specific primers used in RT-PCR for transcript evaluations

\begin{tabular}{|c|c|c|c|c|c|c|}
\hline Genes & Nicotiana sp. tomato & Accession no. ${ }^{a}$ & Gene-specific primers & Primer & Fragment length $^{b}$ & Source \\
\hline \multirow[t]{2}{*}{... } & $M i-1$ & AF039682 & 5'-CTTGCGTCTACTGACTCTTTCC-3', & VIGS-F & 330 & This study \\
\hline & & & 5'-CTAAGAGGAATCTCATCACAGG-3' & $\mathrm{C} 2 \mathrm{~S} 4$ & & Milligan et al. 1998 \\
\hline \multirow[t]{2}{*}{$M E K 2$} & LeMKK2 & AY691331 & 5'-CCATTTGTATGTCTCAGCCTCC-3', & LeMKK2-F & 219 & Ekergren et al. 2003 \\
\hline & & & 5'-GAGGAGGTGGAGGTAACAATG-3' & LeMKK2-R & & \\
\hline \multirow[t]{2}{*}{$S I P K$} & LeMPK1 & AY261512 & 5'-GTCGGATGTGGCTGCACCTC-3', 5'- & LeMPK1-F & 380 & This study \\
\hline & & & CGTTAAAGGCTTCTCTCTGTGG-3' & LeMPK1-R & & \\
\hline \multirow[t]{2}{*}{ Ntf4 } & LeMPK2 & AY261513 & 5'-GCTTATGGAGTTGATTGGCACC-3', & LeMPK2-F & 398 & This study \\
\hline & & & 5'-ACAGACAATCCAACAGCAAACG-3' & LeMPK2-R & & \\
\hline \multirow[t]{2}{*}{$W I P K$} & LeMPK3 & AY261514 & 5'-ATGTGATTCCTCCGCCCTTACG-3', & LeMPK3-F & 563 & Ekergren et al. 2003 \\
\hline & & & 5'-ACACTGTTGCTAACTGCTGGCG-3' & LeMPK3-R & & \\
\hline
\end{tabular}

a Accession numbers for tomato genes.

$\mathrm{b}$ The length (measured in $\mathrm{bp}$ ) of tomato cDNA fragments amplified with the corresponding primers.

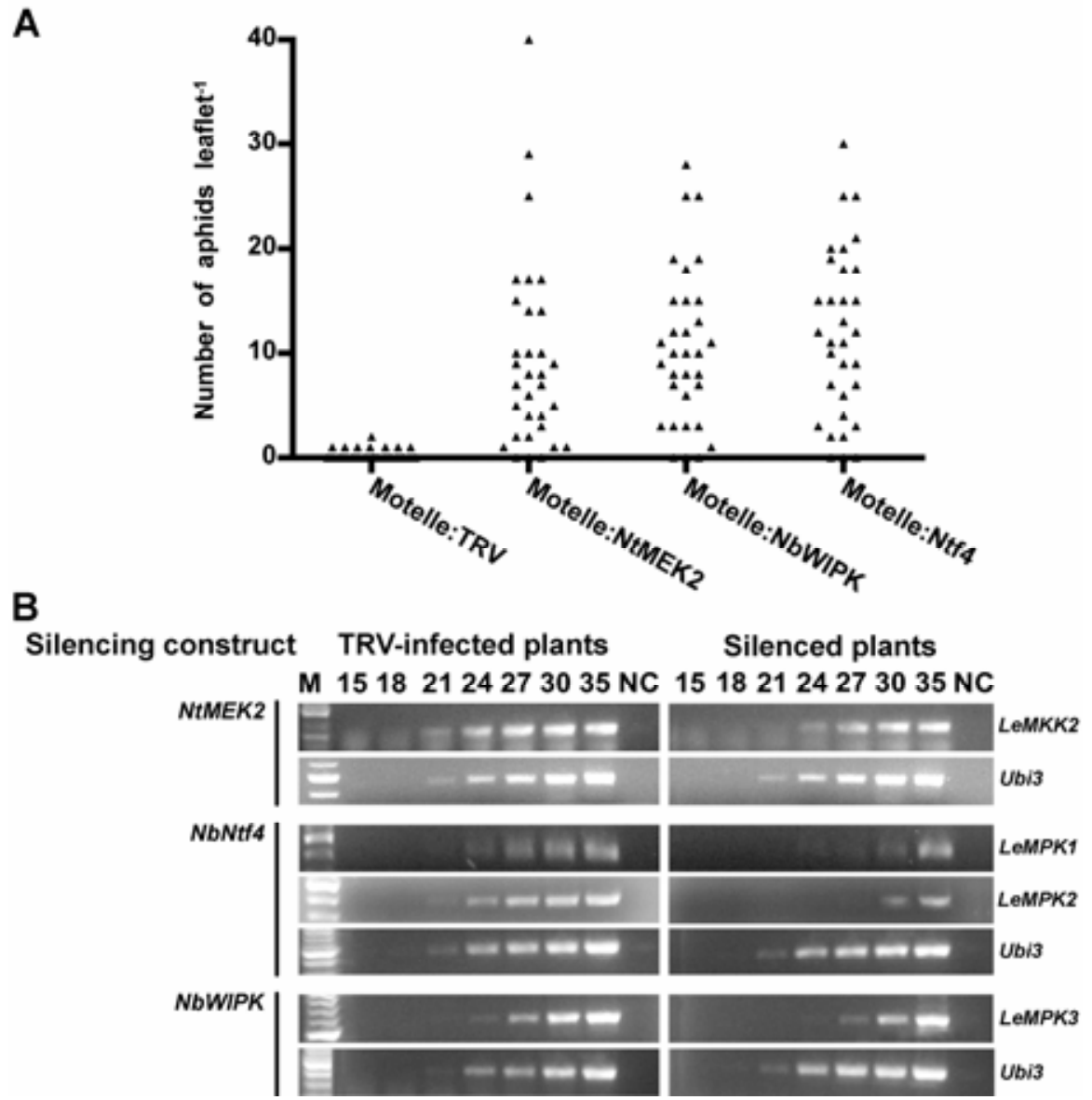

Fig. 8. Aphid survival and gene expression in Motelle (Mi-1/Mi-1) tomato leaflets silenced for members of mitogen-activated protein kinases. Plants were agroinfiltrated with pTRV1 plus pTRV2 empty vector (TRV) or with $N t M E K 2, N b W I P K$, or NbNtf4 constructs used for silencing. Aphid infestations were performed using leaf cages. A, Aphid survival on leaflets agroinfiltrated with the indicated constructs. Triangles represent the number of aphids (adult and nymphs) on a single infested leaflet. For each construct, eight plants were used in each experiment and four leaflets per plant were assayed with aphids. For each construct, four independent experiments were performed. Data from one experiment are presented. B, Effect of TRV-virus-induced gene silencing on transcript levels of targeted genes in tomato leaflets of cv. Motelle ( $M i-1 / M i-1)$. Ethidium bromide-stained $1.5 \%$ agarose gels with reverse transcriptase-polymerase chain reaction (PCR) products. cDNA was synthesized from total RNA isolated from leaflets from plants agroinfiltrated with TRV or TRV containing the indicated construct. Targeted genes are listed to the right of the gels. Except for TRV agroinfiltrated leaflets, all leaflets used in RNA isolation supported aphid growth. Amplification of the tomato ubiquitin Ubi3 gene was used as an internal control for equal cDNA use from control and silenced plants. PCR cycles are as indicated on the top of the panels. Lane 'M' indicates DNA ladder and 'NC' indicates the negative control in which RNA was used as template in the absence of reverse transcriptase. 
telle $(M i-1 / M i-1)$ and Moneymaker (mi-1/mi-1), and the transgenic tomato expressing $N a h G$ in Moneymaker background (Brading et al. 2000). For most experiments, seeds were sown in seedling trays filled with organic planting mix (Sun Gro Horticulture, Bellevue, WA, U.S.A.) and, two to three weeks after germination, were either used directly or transplanted into larger containers. To assist in uniform germination, seedling trays were maintained in a greenhouse in an enclosed structure with misters. After germination, seedlings were grown in growth chambers at $25^{\circ} \mathrm{C}$ and a 16-h light and 8 -h dark cycle. Seedlings grown for $N a h G$ experiments were maintained in similar conditions, except they received low light intensity at $60 \mu \mathrm{E} \mathrm{m}^{-1} \mathrm{~s}^{-2}$. NahG plants grown under these conditions did not develop necrotic spots. Necrotic spots developed in leaflets of both $N a h G$ and VFN $\times N a h G$ plants at the end of the aphid screens performed in a greenhouse. Plants located in the center of the insect cages, where aphid choice assays were performed, had fewer necrotic spots.

At seeding, plants were supplemented with Osmocote (17-610) (Sierra Chemical Company, Milpitas, CA, U.S.A.) and were fertilized biweekly with Tomato MiracleGro (18-18-21) (Stern's MiracleGro Products, Port Washington, NY, U.S.A.). For aphid bioassays, tomato seedlings were transplanted into plastic cups (10-cm diameter, $17 \mathrm{~cm}$ deep) filled with a 1:1 mixture of University of California mix II and blow sand. After transplanting, plants were maintained either in a greenhouse, with temperatures ranging between 22 and $26^{\circ} \mathrm{C}$, or in growth chambers maintained as indicated.

\section{Aphid rearing.}

A clonal colony of the parthenogenetic $\mathrm{Mi}-1$-avirulent potato aphid Macrosiphum euphorbiae was maintained on susceptible tomato cv. UC82B seedlings in an insect cage located in a pesticide-free greenhouse.

To obtain mature one-day-old aphids, mature aphids were transferred to tomato seedlings and allowed to lay progeny. Seedlings were maintained in an insect cage. At $24 \mathrm{~h}$ after transfer, mature aphids were removed and the first instars were allowed to develop to maturity.

\section{Aphid infestations.}

Both choice and no-choice assays were performed in a pesticide-free greenhouse at temperatures ranging from 23 to $26^{\circ} \mathrm{C}$. Unless otherwise stated, these assays were performed as follows. For choice assays, test plants were moved into large cages and several pots with aphid-infested susceptible tomato seedlings, about 20 seedlings in a pot $(12-\mathrm{cm}$ diameter, $10-\mathrm{cm}$ deep), were distributed within the cage, allowing free movement of aphids. At 10 to 15 days after exposure to aphids, individual plants were evaluated by counting the number of aphids on the three most-infested leaflets.

Two distinct no-choice assays were performed. In the first no-choice assay, individual leaflets of seven- to nine-week-old tomato plants were infested with about 25 apterous (wingless) adults and nymphs of potato aphids, using leaf cages. Leaf cages used in these experiments encase an entire leaflet and wrap around the leaf petiole with a nylon mesh fabric, providing adequate ventilation. The fabric was secured with surgical tape and cages were stabilized with a wire inserted in the pot. In the second no-choice assay, where no Mi-1-containing tomato seedlings were used, one-day-old adult aphids were used to infest four-week-old tomato seedlings.

For RNA analyses, 20 apterous adults and nymphs of potato aphids were caged onto a tomato leaflet, on the fourth or fifth leaf of nine-week-old tomato plants. Leaf cages were the same as described for the no-choice assay. Three cages were used per plant and two plants were infested for each timepoint and tissue pooled. Infested leaflets were collected at the indicated timepoints. Cages were removed and leaflets were sprayed with $1 \%$ (wt/vol) SDS to force aphids to withdraw their stylets prior to careful removal using a paintbrush. Tomato leaflets were cut using a razor blade and were immediately frozen in liquid nitrogen. Tissues were stored at $-80^{\circ} \mathrm{C}$ until RNA isolation. Two independent experiments were performed.

\section{Statistical analyses.}

Data was analyzed using analysis of variance (ANOVA) using the statistical packages Statistix (Statistix, Tallahassee, FL, U.S.A.) or SAS (SAS Institute 2002). Paired comparisons were performed using the $t$ test. When variances were significantly different, data was log-transformed before analysis. Data in percentage values were arcsin-transformed before analysis. Daily aphid survival was analyzed using repeated measures of ANOVA. Results within individual days were tested using $t$ test.

\section{BTH treatment.}

Actigard 50WG Plant Activator (Syngenta, Greensboro, NC, U.S.A.), which contains 50\% (wt/wt) active ingredient BTH, was used. Each tomato plant was sprayed with about $5 \mathrm{ml}$ of aqueous suspension of $1.5 \mathrm{mM}$ BTH.

\section{SA extraction and analysis.}

Leaves from three-week-old tomato seedlings were used for determination of foliar SA levels. For HR induction, each leaflet of one branch was infiltrated on the abaxial side with a $10^{8}$ CFU ml ${ }^{-1}$ aqueous suspension of $P$. syringae pv. syringae, using a 1-ml needleless syringe (Smith et al. 1991). Control plants were infiltrated with water. Two plants were used for each genotype treatment. Leaf tissue was collected $24 \mathrm{~h}$ after infiltration, was frozen immediately in liquid nitrogen, and was stored at $-80^{\circ} \mathrm{C}$.

Samples from each plant were ground to a fine powder with a mortar and pestle in liquid nitrogen and were stored at $-80^{\circ} \mathrm{C}$, prior to SA determination. SA concentration was measured in duplicate from each sample. SA concentration in samples was determined on an Agilent XD C18 column using an Agilent 1100 HPLC and was detected fluorometrically. The isocratic mobile phase was $75 \%$ (vol/vol) $20 \mathrm{mM}$ formate, $\mathrm{pH} \mathrm{3.8,20 \%}$ (vol/vol) $\mathrm{MeOH}, 5 \%$ acetonitrile. Flow rate was $0.75 \mathrm{ml} \mathrm{min} \mathrm{min}^{-1}$ at $35^{\circ} \mathrm{C}$. SAG was determined by quantitating the free SA released after acid hydrolysis of bound fraction. Total SA measurements were used for statistical analysis.

\section{Selection of plants with $\mathrm{Mi}-1$ gene.}

The presence of the Solanum peruvianum L. introgressed region, which spans the $M i$ locus, in tomato seedlings was evaluated using a STS marker REX-1 as described by Williamson and associates (1994).

\section{RNA isolation \\ for RNA blot hybridization and RNA blot hybridization.}

Total RNA was isolated as described previously (Martinez de Ilarduya and Kaloshian 2001). Total RNAs (15 $\mu$ g per lane) were separated on a $1.2 \%$ (wt/vol) agarose-formaldehyde gel and were transferred to a nylon membrane (Osmonics Inc., Westborough, MA, U.S.A.) in $10 \times \mathrm{SSC}(1 \times \mathrm{SSC}$ is $0.15 \mathrm{M}$ $\mathrm{NaCl}$ plus $0.015 \mathrm{M}$ sodium citrate, $\mathrm{pH}$ 7.0). The gel was stained with ethidium bromide to assure equivalent loading per lane. The $P R-1$ cDNA clone, also known as $P 4$, was provided by P. de Wit (Wageningen University, The Netherlands). A soybean rRNA clone was used as a control to verify equal loading between lanes. DNA probes were labeled with ${ }^{32} \mathrm{P}-\alpha-\mathrm{dCTP}$, using the Rediprime labeling kit (Amersham, Arlington Heights, 
IL, U.S.A.) according to the manufacturer's instructions. The RNA blot was prehybridized for $2 \mathrm{~h}$ at $42^{\circ} \mathrm{C}$ and was hybridized for $16 \mathrm{~h}$ at $42^{\circ} \mathrm{C}$ as described by Kaloshian and associates (1998). Unincorporated probes were washed away in $0.5 \times \mathrm{SSC}$ containing $0.1 \%(\mathrm{wt} / \mathrm{vol}) \mathrm{SDS}$ at $65^{\circ} \mathrm{C}$ for $30 \mathrm{~min}$. Hybridization results were visualized by autoradiography using Kodak XAR-5 film. Probes were stripped by pouring boiling $0.5 \%$ (vol/vol) SDS on the membrane and allowing it to cool to room temperature. The blot was checked for complete removal of the probe and reused.

\section{RNA isolation and RT-PCR.}

Total RNA was extracted using Trizol (Invitrogen Life Technologies Co., Carlsbad, CA, U.S.A.) according to the manufacturer's recommendation, and $5 \mu \mathrm{g}$ of total RNA was treated with 1 U RNase-free DNaseI (Promega, Madison, WI, U.S.A.). DNaseI was removed by phenol/chloroform extraction, and cDNAs were synthesized using a $0.5 \mu \mathrm{g}$ oligo $(\mathrm{dT})_{18}$ primer (MBI Fermentas, Amherst, NY, U.S.A.) and Superscript II reverse transcriptase (Invitrogen Life Technologies Co.) to a final volume of $20 \mu \mathrm{l}$. In PCR, the tomato ubiquitin Ubi3 gene transcripts were amplified as an internal control for equal cDNA use from control and silenced plants. To amplify the tomato ubiquitin, the primers Ubi3-dir 5'-GAAAACCCTAACGGGG AAG-3' and Ubi3-rev 5'-GCCTCCAGCCTTGTTGTAAA-3' were used. To confirm lack of genomic DNA contamination, $200 \mathrm{ng}$ of DNase-treated RNA was also used as template. PCR was performed in a $25-\mu \mathrm{l}$ volume using $2 \mu \mathrm{l}$ of cDNA, and each reaction included denaturation at $94^{\circ} \mathrm{C}$ for $45 \mathrm{~s}$, annealing at $60^{\circ} \mathrm{C}$ for $45 \mathrm{~s}$, and elongation at $72^{\circ} \mathrm{C}$ for $1 \mathrm{~min}$. The number of cycles used for each transcript is indicated on the gel figures. The amplified products were analyzed on $1.5 \%$ (wt/vol) agarose gels stained with ethidium bromide. When needed, amplification products were purified using the Concert purification system (Gibco BRL, Baltimore, MD, U.S.A.) and were directly ligated into a pGEM T-Easy vector (Promega). Bacterial transformation and DNA preparation followed established protocols (Sambrook et al. 1989). Purified recombinant plasmids were sequenced.

\section{Determination of $\mathrm{Mi}-1$ transcript levels.}

Since $M i-1$ is a member of a multigene family, gene-specific primers were designed that allowed amplification of the $M i-1$ gene. The high nucleotide sequence identity between the cloned $\mathrm{Mi}-\mathrm{I}$ homologs restricted the VIGS targeted area and the area amplified by the gene-specific primers to overlapping regions (Milligan et al. 1998). One of the primers used in PCR annealed to a region within the VIGS targeted area, and the second primer annealed to a region outside the VIGS targeted area (Table 1). Therefore, a region overlapping with the targeted sequences in VIGS was amplified.

\section{Virus constructs.}

The TRV vector, derived from the bipartite TRV virus, used in these experiments was previously described (Liu et al. 2002). The VIGS construct for Nicotiana tabacum MEK2 and N. benthamiana WIPK were also previously described (Ekengren et al. 2003). The TRV:NbNtf4 construct was obtained from S. Dinesh Kumar (Yale University, New Have, CT, U.S.A.) and spanned nucleotides 870 to 1,382 of clone accession number X83880. The VIGS $M i-1$ construct was engineered by cloning a 300-bp Mi- 1 cDNA fragment and amplification using primers C1/2Do and C2S4 (Martinez de Ilarduya and Kaloshian 2001). The amplified fragment was cloned into pGEM T-Easy vector and was restricted with $S p h$ I and treated with T4 DNA polymerase. The resulting fragment was digested with SacI and was ligated into pTRV2. The resulting plasmid was transformed into Agrobacterium tumefaciens GV3101.
Agrobacterium tumefaciens-mediated virus infection.

Cultures of A. tumefaciens GV3101 (1 ml each) containing each of the constructs derived from pTRV2, empty vector control, and pTRV1 were grown overnight in Luria-Bertani (LB) medium containing $50 \mu \mathrm{g}$ of kanamycin per milliliter and 50 $\mu \mathrm{g}$ of gentomycin per milliliter at $28^{\circ} \mathrm{C}$. Each overnight culture was used to inoculate $50-\mathrm{ml}$ cultures of LB containing the same antibiotics and $10 \mathrm{mM}$ MES (2-[N-Morpholino] ethane sulfonic acid) and $20 \mu \mathrm{M}$ acetosyringone. The cultures were grown overnight at $28^{\circ} \mathrm{C}$. Agrobacterium cultures were pelleted, resuspended in infiltration buffer containing $10 \mathrm{mM} \mathrm{MgCl}_{2}, 10$ $\mathrm{mM}$ MES, and $200 \mu \mathrm{M}$ acetosyringone and were adjusted to an optical density at $600 \mathrm{~nm}$ of 1.0. Cells were incubated at room temperature for $3 \mathrm{~h}$ before use. An equal volume of pTRV1 Agrobacterium culture was mixed with one of the pTRV2 cultures before infiltration.

The abaxial side of leaflets of two-week-old seedlings were infiltrated with $A$. tumefaciens cells (agroinfiltration), using a 3-ml needleless syringe. Two weeks after infiltration, plants were transplanted into plastic cups $(10-\mathrm{cm}$ diameter, $17 \mathrm{~cm}$ deep) filled with a 1:1 mixture of University of California mix II and blow sand. Plants were maintained at $19^{\circ} \mathrm{C}$ until ready for aphid assays. Since $\mathrm{Mi}$ - 1 -mediated aphid resistance is developmentally regulated and tomato plants used in VIGS were grown at $19^{\circ} \mathrm{C}$, plants reached the proper developmental stage for aphid screens at five to six weeks after infiltration.

\section{ACKNOWLEDGMENTS}

We thank S. Edwards for help with figures, R. Tayyar, B. Ehdaie, and T. Young for statistical analyses, and P. Springer for critical reading of the manuscript. We also thank S. Dinesh-Kumar (Yale University) for the TRV clones, C. Smart (Cornell University, NY, U.S.A.) for NahG tomato seeds, and A. Tally (Syngenta Crop Protection Inc.) for providing Actigard 50WG Plant Protector. This research was supported in part by grants to I. Kaloshian from the United States Department of Agriculture-National Research Initiative Competitive Grants Program (no. 2000-02876) and University of California Agricultural Experiment Station.

\section{LITERATURE CITED}

Brading, P. A., Hammond-Kosack, K. E., Parr, A., and Jones, J. D. 2000 Salicylic acid is not required for $C f$-2- and $C f$-9-dependent resistance of tomato to Cladosporium fulvum. Plant J. 23:305-318.

Branch, C., Hwang, C.-F., Navarre, D. A., and Williamson, V. M. 2004. Salicylic acid is part of the $M i$-1-mediated defense response to rootknot nematode in tomato. Mol Plant-Microbe Interact 17:351-356.

Burch-Smith, T. M., Anderson, J. C., Martin, G. B., and Dinesh-Kumar, S P. 2004. Applications and advantages of virus-induced gene silencing for gene function studies in plants. Plant J. 39:734-46.

Chaman, M. E., Copaja, S. V., and Argandona, V. H. 2003. Relationships between salicylic acid content, phenylalanine ammonia-lyase (PAL) activity, and resistance of barley to aphid infestation. J. Agric. Food Chem. 51:2227-2231.

Cooper, W. C., Jia, L., and Goggin, F. L. 2004. Acquired and R-genemediated resistance against the potato aphid in tomato. J. Chem. Ecol. 30:2527-2542.

del Pozo, O., Pedley, K. F., and Martin, G. B. 2004. MAPKKK $\alpha$ is a positive regulator of cell death associated with both plant immunity and disease. EMBO (Eur. Mol. Biol. Organ.) J. 23:3072-82.

Ding, S. W., Li, H. W., Lu, R., Li, F., and Li, W. X. 2004. RNA silencing: A conserved antiviral immunity of plants and animals. Virus Res. 102:109-115.

Ekengren, S. K., Liu, Y., Schiff, M., Dinesh-Kumar, S. P., and Martin, G. B. 2003. Two MAPK cascades, NPR1, and TGA transcription factors play a role in Pto-mediated disease resistance in tomato. Plant $\mathrm{J}$. 36:905-917.

Flor, H. H. 1971. Current status of the gene-for-gene concept. Annu. Rev. Phytopathol. 9:275-296.

Friedrich, L., Lawton, K., Ruess, W., Masner, P., Specker, N., Rella, M. G., Meier, B., Dincher, S., Staub, T., Uknes, S., Metraux, J. P., Kessmann, H., and Ryals, J. 1996. A benzothiadiazole derivative induces systemic acquired resistance in tobacco. Plant J. 10:61-70.

Gaffney, T., Friedrich, L., Vernooij, B., Negrotto, D., Nye, G., Uknes, S. 
Ward, E., Kessmann, H., and Ryals, J. 1993. Requirement of salicylic acid for the induction of systemic acquired resistance. Science 261:754-756.

Glazebrook, J. 2001. Genes controlling expression of defense responses in Arabidopsis-2001 status. Curr. Opin. Plant Biol. 4:301-308.

Goggin, F. L., Williamson, V. M., and Ullman, D. E. 2001. Variability in the response of Macrosiphum euphorbiae and Myzus persicae (Hemiptera: Aphididae) to the tomato resistance gene Mi. Environ. Entomol. 30:101-106.

Hammond-Kosack, K. E., and Parker, J. E. 2003. Deciphering plant-pathogen communication: Fresh perspectives for molecular resistance breeding. Curr. Opin. Biotechnol. 14:177-193.

Havlickova, H., Cvikrova, M., Eder, J., and Hrubcova, M. 1998. Alterations in the levels of phenolics and peroxidase activities induced by Rhopalosiphum padi (L) in two winter wheat cultivars. Z. Pflanzenk. Pflanzen. 105:140-148.

Heck, S., Grau, T., Buchala, A., Metraux, J. P., and Nawrath, C. 2003. Genetic evidence that expression of $N a h G$ modifies defence pathways independent of salicylic acid biosynthesis in the Arabidopsis-Pseudomonas syringae pv. tomato interaction. Plant J. 36:342-352.

Holley, S. R., Yalamanchili, R. D., Moura, D. S., Ryan, C. A., and Stratmann, J. W. 2003. Convergence of signaling pathways induced by systemin, oligosaccharide elicitors, and ultraviolet-B radiation at the level of mitogen-activated protein kinases in Lycopersicon peruvianum suspension-cultured cells. Plant Physiol. 132:1728-1738.

Ichimura, K., Shinozaki, K., Tena, G., Sheen, J., Henry, Y., Champion, A., Kreis, M., Zhang, S. Q., Hirt, H., Wilson, C., Heberle-Bors, E., Ellis, B. E., Morris, P. C., Innes, R. W., Ecker, J. R., Scheel, D., Klessig, D. F., Machida, Y., Mundy, J., Ohashi, Y., and Walker, J. C. 2002. Mitogenactivated protein kinase cascades in plants: A new nomenclature. Trends Plant Sci. 7:301-308

Jin, H., Axtell, M. J., Dahlbeck, D., Ekwenna, O., Zhang, S., Staskawicz, B., and Baker, B. 2002. NPK1, an MEKK1-like mitogen-activated protein kinase kinase kinase, regulates innate immunity and development in plants. Dev. Cell 3:291-7.

Jin, H., Liu, Y., Yang, K. Y., Kim, C. Y., Baker, B., and Zhang, S. 2003. Function of a mitogen-activated protein kinase pathway in $N$ genemediated resistance in tobacco. Plant J. 33:719-31.

Kaloshian, I. 2004. Gene-for-gene disease resistance: Bridging insect pest and pathogen defense. J. Chem. Ecol. 30:2421-2439.

Kaloshian, I., and Walling, L. L. 2005. Hemipterans as plant pathogens. Annu. Rev. Phytopathol. 43:491-521.

Kaloshian, I., Lange, W. H., and Williamson, V. M. 1995. An aphid resistance locus is tightly linked to the nematode resistance gene, $M i$, in tomato. Proc. Natl. Acad. Sci. U.S.A. 92:622-625.

Kaloshian, I., Kinsey, M. G., Ullman, D. E., and Williamson, V. M. 1997. The impact of Meul-mediated resistance in tomato on longevity, fecundity and behavior of the potato aphid, Macrosiphum euphorbiae. Entomol. Exp. Appl. 83:181-187.

Kaloshian, I., Yaghoobi, J., Liharska, T., Hontelez, J., Hanson, D., Hogan, P., Jesse, T., Wijbrandi, J., Simons, G., Vos, P., Zabel, P., and Williamson, V. M. 1998. Genetic and physical localization of the root-knot nematode resistance locus $M i$ in tomato. Mol. Gen. Genet. 257:376-385.

Kaloshian, I., Kinsey, M. G., Williamson, V. M., and Ullman, D. E. 2000. Mi-mediated resistance against the potato aphid Macrosiphum euphorbiae (Hemiptera: aphididae) limits sieve element ingestion. Environ. Entomol. 29:690-695

Kunkel, B. N., and Brooks, D. M. 2002. Cross talk between signaling pathways in pathogen defense. Curr. Opin. Plant Biol. 5:325-331.

Liu, Y., Schiff, M., and Dinesh-Kumar, S. P. 2002. Virus-induced gene silencing in tomato. Plant J. 31:777-786.

Liu, Y., Schiff, M., and Dinesh-Kumar, S. P. 2004. Involvement of MEK1 MAPKK, NTF6 MAPK, WRKY/MYB transcription factors, COII and CTR1 in $\mathrm{N}$-mediated resistance to Tobacco mosaic virus. Plant $\mathrm{J}$ 38:800-809.

Martinez de Ilarduya, O., and Kaloshian, I. 2001. Mi-1.2 transcripts accumulate ubiquitously in root-knot nematode resistant Lycopersicon esculentum. J. Nematol. 33:116-120.

Martinez de Ilarduya, O., Moore , A. E., and Kaloshian, I. 2001. The tomato Rmel locus is required for $\mathrm{Mi}-1$-mediated resistance to root-knot nematodes and the potato aphid. Plant J. 27:417-425.

Martinez de Ilarduya, O., Xie, Q., and Kaloshian, I. 2003. Aphid-induced defense responses in $\mathrm{Mi}$-1-mediated compatible and incompatible tomato interactions. Mol. Plant-Microbe Interact. 16:699-708.

Martinez de Ilarduya, O., Nombela, G., Hwang, C.-F., Williamson, V. M., Muñiz, M., and Kaloshian, I. 2004. Rme1 is necessary for Mi-1-medi- ated resistance and acts early in the resistance pathway. Mol. PlantMicrobe Interact. 17:55-61.

Mayrose, M., Bonshtien, A., and Sessa, G. 2004. LeMPK3 is a mitogenactivated protein kinase with dual specificity induced during tomato defense and wounding responses. J. Biol. Chem. 279:14819-14827.

Milligan, S. B., Bodeau, J., Yaghoobi, J, Kaloshian, I, Zabel, P., and Williamson, V. M. 1998. The root-knot nematode resistance gene $M i$ from tomato is a member of leucine zipper, nucleotide binding, leucinerich repeat family of plant genes. Plant Cell 10:1307-1319.

Moran, P. J., Cheng, Y. F., Cassell, J. L., and Thompson, G. A. 2002. Gene expression profiling of Arabidopsis thaliana in compatible plant-aphid interactions. Arch. Insect Biochem. Physiol. 51:182-203.

Nimchuk, Z., Eulgem, T., Holt, B. F., 3rd, and Dangl, J. L. 2003. Recognition and response in the plant immune system. Annu. Rev. Genet. 37:579-609.

Nombela, G., Williamson, V. M., and Muñiz, M. 2003. The root-knot nematode resistance gene $\mathrm{Mi}-1.2$ of tomato is responsible for resistance against the whitefly Bemisia tabaci. Mol. Plant-Microbe Interact. 16:645-649.

O'Donnell, P. J., Schmelz, E. A., Moussatche, P., Lund, S. T., Jones, J. B., and Klee, H. J. 2003. Susceptible to intolerance-A range of hormonal actions in a susceptible Arabidopsis pathogen response. Plant J. 33:245257.

Pascual, S., Avilés, M., Nombela, G., Muñiz, M., and Beitia, F. 2000. Development of Bemisia tabaci (biotype Q) on tomato cultivars with / without the Mi gene. Med. Fac. Landbouww. Univ. Gent. 65/2a:291292.

Pedley, K. F., and Martin, G. B. 2004. Identification of MAPKs and their possible MAPK kinase activators involved in the Pto-mediated defense response of tomato. J. Biol. Chem. 279:49229-49235.

Romeis, T., Piedras, P., Zhang, S., Klessig, D. F., Hirt, H., and Jones, J. D. 1999. Rapid Avr9- and $C f$-9-dependent activation of MAP kinases in tobacco cell cultures and leaves: Convergence of resistance gene, elicitor, wound, and salicylate responses. Plant Cell 11:273-287.

Romeis, T., Ludwig, A. A., Martin, R., and Jones, J. D. 2001. Calcium-dependent protein kinases play an essential role in a plant defence response. EMBO (Eur. Mol. Biol. Organ.) J. 20:5556-5567.

Rossi, M., Goggin, F. L., Milligan, S. B., Kaloshian, I., Ullman, D. E., and Williamson, V. M. 1998. The nematode resistance gene $M i$ of tomato confers resistance against the potato aphid. Proc. Natl. Acad. Sci. U.S.A. 95:9750-9754.

Sambrook, J., Fritsch, E. F., and Maniatis, T. 1989. Molecular Cloning: A Laboratory Manual. Cold Spring Harbor Laboratory Press, Cold Spring Harbor, NY, U.S.A..

SAS Institute. 2002. 2002-2003 v9.1 for Windows. SAS Institute Inc. Cary, NC, U.S.A

Schenk, P., Kazan, K., Wilson, I., Anderson, J., Richmond, T., Somerville, S., and Manners, J. 2000. Coordinated plant defense responses in Arabidopsis revealed by microarray analysis. Proc. Natl. Acad. Sci. U.S.A. 97:11655-11660.

Sharma, P. C., Ito, A., Shimizu, T., Terauchi, R., Kamoun, S., and Saitoh, H. 2003. Virus-induced silencing of WIPK and SIPK genes reduces resistance to a bacterial pathogen, but has no effect on the INF1-induced hypersensitive response (HR) in Nicotiana benthamiana. Mol. Gen. Genomics 269:583-591.

Smith, J. A., Hammerschmidt, R., and Fulbright, D. W. 1991. Rapid induction of systemic resistance in cucumber by Pseudomonas syringae pv. syringae. Physiol. Mol. Plant Pathol. 38:223-235.

Tena, G., Asai, T., Chiu, W. L., and Sheen, J. 2001. Plant mitogen-activated protein kinase signaling cascades. Curr. Opin. Plant Biol. 4:392400.

van Kan, J., Cozijnsen, T., Danhash, N., and de Wit, P. 1995. Induction of tomato stress protein mRNAs by ethephon, 2,6-dichloroisonicotinic acid and salicylate. Plant Mol. Biol. 27:1205-1213.

Williamson, V. M., Ho, J.-Y., Wu, F. F., Miller, N., and Kaloshian, I. 1994 A PCR-based marker tightly linked to the nematode resistance gene, $M i$, in tomato. Theor. Appl. Genet. 87:757-763.

Zhang, S. Q., and Klessig, D. F. 1998. Resistance gene $N$-mediated de novo synthesis and activation of a tobacco mitogen-activated protein kinase by tobacco mosaic virus infection. Proc. Natl. Acad. Sci. U.S.A. 95:7433-7438.

Zhang, S., and Klessig, D. F. 2000. Pathogen-induced MAP kinases in tobacco. Results Probl. Cell Differ. 27:65-84.

Zhang, S. Q., and Klessig, D. F. 2001. MAPK cascades in plant defense signaling. Trends Plant Sci. 6:520-527. 